\title{
Suicide: The story of data
}

Ho Manh Toan

Phenikaa University

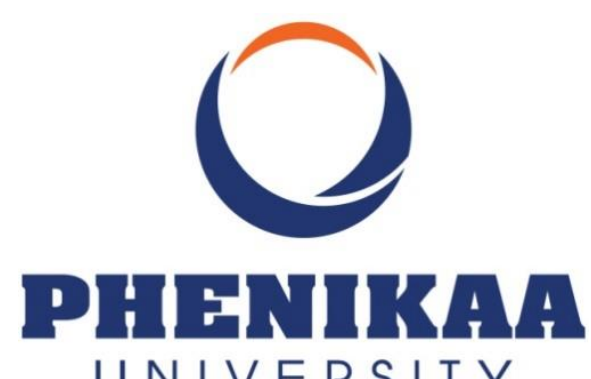

UN I VER S I T Y

February 16, 2021

This short paper explores data articles that are related to or about suicidal behaviors. The author used the keyword "suicide" to find related data articles on three prominent journal articles: Scientific Data, Data in Brief, and Data.

The author then manually reads each result to make sure that it qualifies. Finally, only seven articles were chosen. The results are presented in Table 1.

Table 1. List of data articles on Scientific Data, Data in Brief, and Data

\begin{tabular}{|l|l|l|l|l|}
\hline Data & Year & Sample Size & Subject & Technique \\
\hline$[1]$ & 2019 & $\begin{array}{l}44 \text { people (442,270 unique } \\
\text { variants) }\end{array}$ & $\begin{array}{l}\text { Medical genomics; } \\
\text { Molecular neuroscience; } \\
\text { Next-generation } \\
\text { sequencing }\end{array}$ & Genetic \\
\hline$[2]$ & 2020 & 10,067 participants & $\begin{array}{l}\text { Infectious diseases and } \\
\text { public health }\end{array}$ & Survey \\
\hline$[3]$ & 2015 & $\begin{array}{l}775 \text { people (6 SNPs) } \\
\text { Biology }\end{array}$ & Genetic \\
\hline$[4]$ & 2020 & $\begin{array}{l}32,018 \text { depressive posts and } \\
32,021 \text { non-depressive posts }\end{array}$ & $\begin{array}{l}\text { Artificial Intelligence; } \\
\text { Natural Language } \\
\text { Processing (NLP); } \\
\text { Machine Learning }\end{array}$ & Text mining \\
\hline$[5]$ & 2020 & $\begin{array}{l}\text { 169 patients } \\
\text { Psychiatry and Mental } \\
\text { Health }\end{array}$ & Survey \\
\hline
\end{tabular}




\begin{tabular}{|l|l|l|l|l|}
\hline$[6]$ & 2017 & 20 children & Medicine; Psychology & Case review \\
\hline$[7]$ & 2017 & None & $\begin{array}{l}\text { Psychology: Clinical } \\
\text { Psychology }\end{array}$ & Measurements \\
\hline
\end{tabular}

There are several points that we can observe. Firstly, there has been an interdisciplinary effort to understand suicide better. Aside from the survey $[2,5,6]$, text mining [4] and genetic sequencing [1,3] were also used to find the causes or predictive behaviors of suicide. Secondly, most of these articles are relatively new, and the earliest was from 2015 [3].

The availability of datasets can be attributed to the establishment of data journals and the open access movement [8]. However, it is notable that experts have been warning about the increased risk of suicide over the past two decades $[9,10]$.

The study of suicide had been established in the $18^{\text {th }}$ century with a classic work from Émile Durkheim [11], and later it has been developed by many social scientists [12-14].

However, a glance at the question inside the surveys $[2,5]$ left a sour taste. For instance, the suicide-related question in a survey was:

"Do you think about committing suicide, and are these thoughts persistent and related to COVID-19 issues?'

Even the answer is quite simple: Yes or No.

Understandably, a sensitive issue like suicide is hard for studying through a survey. Nonetheless, a complex and pressing matter should not be treated as an afterthought.

Indeed, the problem could result from the philosophical nature of suicide and the hesitation of suicide-related theories. A person arrives at such a finale of his/her life, indicating a disfunction of the mindsponge mechanism [15].

Theoretically speaking, the overload numbs the mindsponge process, preventing a person from processing, filtering, and rejecting values and information. Thus, the numbness will eventually require the system to restart itself. This idea can be studied further with the help of the flexibility of Bayesian analysis [16].

We still have a long way to go until we can fully understand why we decide to take our lives. Hopefully, we will soon understand it enough to help those suffering in the dark. 


\section{References}

[1] Tombácz, D., et al. (2019). Whole-exome sequencing data of suicide victims who had suffered from major depressive disorder. Scientific Data, 6(1), 1-10.

[2] Pakpour, A. H., Al Mamun, F., Hosen, I., Griffiths, M. D., \& Mamun, M. A. (2020). A population-based nationwide dataset concerning the COVID-19 pandemic and serious psychological consequences in Bangladesh. Data in Brief, 33, 106621.

[3] Ropret, S., Zupanc, T., Komel, R., \& Paska, A. V. (2015). Data in support of association study of the brain-derived neurotrophic factor gene SNPs and completed suicide in the Slovenian sample. Data in Brief, 4, 529-533.

[4] Narynov, S., Mukhtarkhanuly, D., \& Omarov, B. (2020). Dataset of depressive posts in Russian language collected from social media. Data in Brief, 29, 105195.

[5] Pardo-de-Santayana, G., et al. (2020). Data regarding active psychosis and functional outcome, among other clinical variables, during early phases of the illness in first-episode psychosis in the PAFIP 10-year follow-up program. Data in Brief, 30, 105599.

[6] Pierce, M. C., et al. (2017). Dataset on psychosocial risk factors in cases of fatal and near-fatal physical child abuse. Data in Brief, 14, 107.

[7] Bondi, B. C., Pepler, D. J., Motz, M., \& Andrews, N. C. (2020). Cumulative risk and protection measures data. Data in Brief, 32, 106129.

[8] Vuong, Q. H. (2017). Open data, open review and open dialogue in making social sciences plausible. Nature: Scientific Data Updates. Retrieved from http://blogs.nature.com/scientificdata/2017/12/12/authors-corner-open-dataopen-review-and-open-dialogue-in-making-social-sciences-plausible/

[9] Winerman, L. (2019). By the numbers: An alarming rise in suicide. Monitor of Psychology, 50(1), 80.

[10] Befrienders Worldwide. (2021). Suicide Statistics. Befrienders Worldwide. Retrieved from https://www.befrienders.org/suicide-statistics

[11] Durkheim, E. (1897). Le suicide: étude de sociologie. F. Alcan

[12] Gunn, J. F., \& Lester, D. (2015). Theories of suicide: Past, present and future. Charles C Thomas Publisher.

[13] Joiner, T. (2005). Why people die by suicide. Harvard University Press. 
[14] O'Connor, R. C. (2011). Towards an integrated motivational-volitional model of suicidal behaviour. International handbook of suicide prevention: Research, Policy and Practice, 1, 181-198.

[15] Vuong, Q. H. (2016). Global mindset as the integration of emerging socio-cultural values through mindsponge processes: A transition economy perspective. In: J. Kuada (ed.) Global Mindsets: Exploration and Perspectives (pp. 109-126). London: Routledge.

[16] La, V. P., \& Vuong, Q. H. (2019). bayesvl: Visually learning the graphical structure of Bayesian networks and performing MCMC with 'Stan'. The Comprehensive $R$ Archive Network. Available from: https://cran.r-project.org/package=bayesvl. 